\title{
Hyperglycaemia-induced subcellular redistribution of GLUT1 glucose transporters in cultured human term placental trophoblast cells
}

\author{
T. Hahn ${ }^{1}$, D. Hahn ${ }^{1}$, A. Blaschitz ${ }^{1}$, E. T. Korgun ${ }^{1}$, G. Desoye ${ }^{2}$, G. Dohr ${ }^{1}$ \\ ${ }^{1}$ Institute of Histology and Embryology, University of Graz, Austria \\ ${ }^{2}$ Department of Obstetrics and Gynaecology, University of Graz, Austria
}

\section{Abstract}

Aims/hypothesis. We have recently shown that hyperglycaemia down-regulates the GLUT1 glucose transport system of term placental trophoblast. The reduction in GLUT1 protein alone was, however, not sufficient to explain the decrease in net glucose uptake, suggesting additional mechanisms. Therefore, we hypothesised that hyperglycaemia in vitro leads to a GLUT1 translocation from the trophoblast surface to intracellular sites.

Methods. This was tested in our study by determining the subcellular distribution of GLUT1 in human term placental trophoblast ( $n=5$ placentas) cultured for $48 \mathrm{~h}$ with 5 compared with $25 \mathrm{mmol} / \mathrm{l} \mathrm{D}$-glucose in vitro using immunogold labelling.

Results. Electron microscopic examination of cell profiles showed that $73 \%$ of total GLUT1 molecules reside in the trophoblast plasma membrane under basal conditions. The reduced GLUT1 expression $(-20 \% ; p<0.05)$ after culture of the cells with $25 \mathrm{mmol} / \mathrm{l}$ glucose was accompanied by an internalisation of plasma membrane GLUT1, resulting in a loss of $40 \%(p<0.05)$ in cell surface transporter labelling. Western blotting identified a characteristically broad band between 55-65 kDa, confirming the specificity of the GLUT1 antiserum.

Conclusion/interpretation. We postulate that in addition to down-regulating human GLUT1 protein concentrations, glucose exerts its autoregulatory effect on hexose transport in term placental trophoblast by altering GLUT1 partitioning between the plasma membrane and intracellular sites in favour of the latter. [Diabetologia (2000) 43: 173-180]

Keywords GLUT1, translocation, glucose, transport, hyperglycaemia, diabetes, trophoblast, placenta, pregnancy, electron microscopy.
Adequate maternal-to-fetal transfer of glucose, the primary substrate for fetal oxidative metabolism, is crucial to sustain the normal development and survival of the fetus in utero, because its own glucose production is minimal [1]. Glucose is transferred across the placenta by stereospecific, sodium-independent

Received: 2 July 1999 and in revised form: 20 August 1999

Corresponding author: Dr. Tom Hahn, Institute of Histology and Embryology, University of Graz, Harrachgasse 21, A-8010 Graz, Austria

Abbreviations: hCG, $\beta$-Human chorionic gonadotrophin; $\mathrm{K}_{\mathrm{M}}$, Michaelis constant; PBG, phosphate buffered saline containing $0.5 \%(\mathrm{w} / \mathrm{v})$ bovine serum albumin and $0.1 \%(\mathrm{w} / \mathrm{v})$ gelatine. facilitated diffusion along a concentration gradient [2]. This mechanism involves carriers that are about 500 amino acids in length and belong to a family of integral membrane proteins which render substrate entry about 10000 times faster than calculated for diffusion across the lipid membrane layer [3]. In spite of the high sequence similarity these glucose transporters are encoded by six different genes designated GLUT1 - GLUT6 [4], which are translated into protein with the exception of the pseudogene GLUT6 [5]. The GLUT1 protein is a high-affinity isoform. Because of its low Michaelis constant $\left(\mathrm{K}_{\mathrm{M}}\right)$, this transporter functions at rates close to maximum velocity. Thus its level of cell surface expression greatly influences the rate of glucose uptake into the cells. The highly tissue-specific expression of GLUT1 in 
situ is restricted to epithelial blood-tissue barriers such as the placental trophoblast [6]. This narrow tissue layer separates the maternal and fetal circulations during pregnancy and thus represents the key regulator of transplacental glucose supply to the fetus [7].

In line with the general notion that placental glucose transporters are regulated by substrate availability and glucocorticoids, rather than by insulin changes [8-10], we have shown that hyperglycaemia (20 and $25 \mathrm{mmol} / \mathrm{l}$ D-glucose) down-regulates the GLUT1 glucose transport system of human term placental trophoblast [11]. This was recently confirmed by others with $20 \mathrm{mmol} / \mathrm{l} \mathrm{D}$-glucose [12]. We speculated that this down-regulation could represent a mechanism to protect fetal development in maternal diabetes. After hyperglycaemia there was, however, no kinetic evidence for a change in the intrinsic activity of the transporters neither in placental trophoblast [11] nor in trophoblast-derived choriocarcinoma cells [13]. The rather moderate extent of GLUT1 protein regulation alone was not sufficient to explain the considerable changes in net glucose uptake measured in these studies. We therefore hypothesised that hyperglycaemia changes the distribution pattern of GLUT1 between the plasma membrane and intracellular sites in human term placental trophoblast, which could have contributed to above apparent discrepancy.

\section{Materials and methods}

The study has been approved by the ethics committee of the University of Graz, Medical Faculty.

Cell culture. Mononucleated trophoblast was isolated from five term human placentas after uncomplicated pregnancy and vaginal delivery as was described in detail elsewhere [14]. Briefly, villous material was digested with a $0.125 \%(\mathrm{v} / \mathrm{v})$ trypsin solution (Gibco Life Technologies, Paisley, UK). The released cells were loaded on top of a Percoll (Pharmacia, Uppsala, Sweden) gradient ranging from $70 \%(\mathrm{v} / \mathrm{v})$ to $10 \%(\mathrm{v} / \mathrm{v})$. After centrifugation the band containing trophoblasts was removed. After extensive washings the trophoblasts were highly purified using immunomagnetic particles (Dynabeads M-280; Dynal, Hamburg, Germany), which had been conjugated with the monoclonal antibody W6/32 (Serotec, Kidlington, UK) against HLA-class I antigens. In the human placenta this antibody reacts only with stromal cells, macrophages, the endothelium and with the extravillous trophoblast. It does not identify villous trophoblast, which is devoid of HLA-class I antigens [15].

Cells were plated at a density of 500 cells $/ \mathrm{mm}^{2}$ into Transwell-COL culture chamber inserts (Costar, Cambridge, Mass., USA) and cultured in DMEM (Gibco) supplemented with $15 \%$ defined fetal bovine serum (HyClone Laboratories, Logan, Utah, USA), $100 \mu \mathrm{g} / \mathrm{ml}$ streptomycin (Gibco), $100 \mathrm{IU} /$ $\mathrm{ml}$ penicillin (Gibco) and $100 \mu \mathrm{g} / \mathrm{ml}$ amphotericin B (Gibco) at $37^{\circ} \mathrm{C}$ in a humidified atmosphere of $5 \% \mathrm{CO}_{2} /$ air. Trophoblast cells were allowed to recover their microvillous surface after the trypsinisation for $24 \mathrm{~h}$ before starting the experiments. After this time $(t=0)$ the cells were further cultured for another $48 \mathrm{~h}$ in medium containing either 5.5 (normoglycaemia) or $25 \mathrm{mmol} / \mathrm{l}$ (hyperglycaemia) D-glucose (Sigma,
Taufkirchen, Germany), or $19.5 \mathrm{mmol} / \mathrm{l}$ D-mannitol (Sigma) as osmotic control plus $5.5 \mathrm{mmol} / \mathrm{l} \mathrm{D}$-glucose, respectively. Osmolality of the culture media (means \pm SD) was $326 \pm 15 \mathrm{mosmol} /$ $\mathrm{kg}$ in media containing $5.5 \mathrm{mmol} / \mathrm{l} \mathrm{D}$-glucose, $338 \pm 12 \mathrm{mosmol} /$ $\mathrm{kg}$ in media containing $25 \mathrm{mmol} / \mathrm{l} \mathrm{D}$-glucose and $340 \pm 16 \mathrm{mo}-$ $\mathrm{smol} / \mathrm{kg}$ in media containing $19.5 \mathrm{mmol} / \mathrm{l} \mathrm{D}-$ mannitol plus $5.5 \mathrm{mmol} / \mathrm{l} \mathrm{D}$-glucose. Media were changed daily and stored at $-40^{\circ} \mathrm{C}$ for further analysis.

Purity and characterisation of cell preparations. Viability of the trophoblasts was assessed by $0.05 \%$ (v/v) trypan blue (JRH Biosciences, Crawley Down, Sussex, UK) dye exclusion during a 2-min incubation and by measuring the concentration of $\beta$ human chorionic gonadotropin (OPUS sandwich immunoassay; Behring Diagnostics, Westwood, Mass., USA) secreted into the culture media.

Immunocytochemistry at the light microscopic level was carried out immediately after isolation and, in addition, after $72 \mathrm{~h}$ in culture. Cells were incubated with the following monoclonal antibodies: (1) anti-cytokeratin clone NCL5D3 (1:50; Monosan, Uden, Netherlands) for the identification of trophoblast cells [16], (2) W6/32 (1:10) and (3) anti-CD68 (1:50; Monosan) for monocyte and macrophage identification, and (4) Fluorescein-isothiocyanate-conjugated Ulex europeaeus lectin (UEA-I) (1:10; Sigma) was used for the identification of endothelial cells [17]. Immunoreactivity was visualised using a FITC-conjugated goat anti-mouse secondary antibody (1:20; Dianova, Hamburg, Germany).

Morphology was examined at the electron microscopic level (see below).

Electron microscopy. During processing the trophoblast cells isolated from $n=5$ placentas remained adherent to the Transwell-COL membrane (Costar) on which they were grown in culture. After washing with PBS the cells were fixed and permeabilised for $10 \mathrm{~min}$ in cold $\left(-20^{\circ} \mathrm{C}\right)$ methanol. The fixative was replaced after $10 \mathrm{~s}$. The cells were washed three times for 5 min with PBS and then transferred to PBS containing $0.5 \%$ (w/v) BSA and $0.1 \%$ (w/v) gelatine (Merck, Darmstadt, Germany) (PBG) supplemented with $20 \%$ (w/v) normal goat serum for blocking. Blocking solution was replaced by a polyclonal GLUT1 antiserum (East Acres, Southbridge, Mass., USA), diluted 1:200 in PBS and, for the controls, by serum of non-immunised rabbits or by antibody diluent. Incubation was carried out for $1 \mathrm{~h}$ at room temperature, followed by three washings for 5 min each in PBG. Subsequently, samples were incubated with the goat anti-rabbit secondary antibody coated with $5 \mathrm{~nm}$ colloidal gold particles (AuroProbe; Amersham, Buckinghamshire, UK) diluted 1:10 in PBG for $1 \mathrm{~h}$ at room temperature, followed by four washings in PBG and one in pure PBS for $10 \mathrm{~min}$ each. The cells were postfixed with $2.5 \%$ (v/v) glutaraldehyde (Fluka Chemie, Buchs, Switzerland) in PBS for 30 min at room temperature and then washed in ultrapure water. The labelling was silver-enhanced for $9 \mathrm{~min}$ at room temperature using the intenSE kit (Amersham). After three washings in ultrapure water the samples were treated with $2 \%(\mathrm{w} / \mathrm{v})$ osmium tetroxide in cacodylate buffer at room temperature for $20 \mathrm{~min}$. The cells were washed with cacodylate buffer (three times for $10 \mathrm{~min}$ ) and subsequently with distilled water for $10 \mathrm{~min}$. Samples were dehydrated in $70 \%$ (v/v) ethanol that was replaced three times after each $15 \mathrm{~min}$. Afterwards they were contrasted with $0.5 \%(\mathrm{w} / \mathrm{v})$ uranyl acetate in $1 \%(\mathrm{w} / \mathrm{v})$ phosphorotungsten acid and $70 \%(\mathrm{v} / \mathrm{v})$ ethanol for 30 min and further dehydrated in $80 \%, 90 \%$ and twice $100 \%$ $(\mathrm{v} / \mathrm{v})$ ethanol for each $15 \mathrm{~min}$. The samples were embedded in resin (TAAB Laboratories Equipment, Aldermaston, UK) after preinfiltration with a terpineol/resin mixture (1:1 and $1: 3$, 
Table 1. Accumulated $\beta$-hCG values in the media of human term placental trophoblast cells

\begin{tabular}{llll}
\hline $\begin{array}{l}\text { Time after } \\
\text { plating }\end{array}$ & \multicolumn{3}{l}{$\beta$-hCG $\left(\mathrm{mIU} / 10^{6}\right.$ cells $)$} \\
\cline { 2 - 4 } & $\begin{array}{l}\text { Normo- } \\
\text { glycaemia }\end{array}$ & $\begin{array}{l}\text { Hyper- } \\
\text { glycaemia }\end{array}$ & $\begin{array}{l}\text { Osmotic } \\
\text { control }\end{array}$ \\
\hline $24 \mathrm{~h}$ & $19(11-64)$ & - & - \\
$48 \mathrm{~h}$ & $81(32-288)$ & $74(24-502)$ & $70(25-294)$ \\
$72 \mathrm{~h}$ & $51(14-172)$ & $56(33-145)$ & $59(42-113)$ \\
\hline
\end{tabular}

Cells were cultured under normoglycaemic conditions for $24 \mathrm{~h}$ and further in the presence of either $5.5 \mathrm{mmol} / 1$ glucose (normoglycaemia) or $25 \mathrm{mmol} / \mathrm{l}$ glucose (hyperglycaemia) or $25 \mathrm{mmol} / \mathrm{l} \mathrm{D}$-mannitol (osmotic control), respectively, for another $48 \mathrm{~h}$. Data are medians and (range)

respectively, for each $15 \mathrm{~min}$ ). Ultrathin (50 $\mathrm{nm}$ ) sections were examined with a Zeiss 902 electron microscope at an accelerating voltage of $50 \mathrm{kV}$. Photographs were taken on Kodak electron microscope film SO 163 at 2 s exposure time.

Specificity of the GLUT1 antiserum. The antiserum was raised against the human erythrocyte glucose transporter and identified a recombinant lambda gt11 bacteriophage in a cDNA library prepared from immunoselected polysomal RNA from adult rat brain. This cDNA predicts a 492 -amino acid protein that has $97.6 \%$ identity to the human hepatoma hexose carrier [18]. The amino acid residues 480-492 of the carboxyl terminus of the deduced sequence of the glucose transporter are bound by the antiserum and it specifically immunoblots the $55 \mathrm{kDa}$ glucose transporter in erythrocyte membranes and the purified erythrocyte transporter [19]. This binding is saturable and competitively inhibited by peptide 480-492 [19]. The antiserum cross-reacts with the HepG2 glucose transporter [20] as well as with GLUT1 in Caco-2 cells [21].

Quantification of GLUT1 distribution. The GLUT1 distribution was quantified by counting immunogold particles in ultrathin sections according to a standard procedure [22]. Three grids among 15-20 from each trophoblast preparation $(n=5)$ were selected on the basis of good morphology at a magnification of $\mathrm{x} 700$. Within each grid, cells that showed the nucleus were randomly chosen and used for counting over the entire cross-sectional profile of a cell. Grid squares were used to outline cytoplasmic fields in which gold particles were counted one after the other. The numbers of gold particles were counted at $\times 30000$ magnification. Higher magnification (up to $\times 85000)$ was chosen if the gold grains were accumulated in clusters. For each experiment ten profiles per grid were scored which were examined in strict sequence, ensuring that no trophoblast cell was scored twice. The average number of gold particles was calculated by subtracting the labelling of a control profile from that of the experimental specimen.

Sodium dodecyl sulphate-PAGE and western blotting. Trophoblast proteins obtained from samples $(n=5)$ after $48 \mathrm{~h}$ in hyperglycaemic culture and respective controls were rendered soluble in Laemmli sample buffer (Sigma) supplemented with Complete protease inhibitor cocktail (Boehringer, Mannheim, Germany). Insoluble material was removed by centrifugation at $100000 \times g$ for $1 \mathrm{~h}$ at $4^{\circ} \mathrm{C}$. Before electrophoresis, samples were boiled for $3 \mathrm{~min}$ at $100^{\circ} \mathrm{C}$.

Equal amounts of protein, determined as described previously [23], were subjected to SDS-PAGE on $8 \%-18 \%$ gradient gels (ExcelGel, Pharmacia) using SDS buffer strips (ExcelGel, Pharmacia). Samples were run for $150 \mathrm{~min}$ at a constant
$600 \mathrm{~V} / 50 \mathrm{~mA} / 30 \mathrm{~W}$. Proteins were transferred onto nitrocellulose membranes (Pharmacia) by semi-dry electroblotting in a buffer containing $0.2 \mathrm{~mol} / \mathrm{l}$ glycine, $25 \mathrm{mmol} / \mathrm{l}$ TRIS and $20 \%$ $(\mathrm{v} / \mathrm{v})$ methanol for $45 \mathrm{~min}$ at $30 \mathrm{~V} / 100 \mathrm{~mA} / 6 \mathrm{~W}$. Successful transfer was confirmed by Ponceau S (Sigma) staining of the blots.

The membranes were blocked for $12 \mathrm{~h}$ with $5 \%(\mathrm{w} / \mathrm{v})$ nonfat dry milk (BioRad, Hercules, Calif., USA) and $0.1 \%(\mathrm{v} / \mathrm{v})$ Tween-20 (Sigma) in $0.14 \mathrm{~mol} / \mathrm{l}$ TRIS-buffered saline $\mathrm{pH}$ 7.2-7.4 at $4{ }^{\circ} \mathrm{C}$. The same solution was used for subsequent washings and as diluent for the antibodies. The blotting membranes were incubated for $1 \mathrm{~h}$ at room temperature with a rabbit antiserum against GLUT1 (East Acres), diluted 1:10000. After washing they were further incubated with goat anti-rabbit IgG horseradish peroxidase conjugate (BioRad) diluted 1:5000 for $1 \mathrm{~h}$ at room temperature. After three washings in $0.14 \mathrm{~mol} / \mathrm{l}$ TRIS-buffered saline, $\mathrm{pH}$ 7.2-7.4, the immunolabelling was made visible using the SuperSignal Ultra chemiluminescence substrate (Pierce, Rockford, Ill., USA) according to the instructions of the manufacturer. Membranes were exposed to Hyperfilm (Amersham).

Control blots were incubated with serum of non-immunised rabbits or the primary antibody was omitted.

Statistics. Experimental data were not normally distributed (Kolmogoroff-Smirnov test) and thus presented as median with range. Statistical analysis was done by one-way non-parametric ANOVA (Kruskal-Wallis procedure) followed by the Mann-Whitney U test. A level of less than 0.05 was chosen to identify significant differences.

\section{Results}

Characterisation of cells. Viability of the cells was greater than $90 \%$ by trypan blue exclusion. The cytokeratin antibody stained approximately $85 \%$ of the cells immediately after isolation and $90-95 \%$ after $72 \mathrm{~h}$ in culture. Of the freshly prepared cells $10 \%$ reacted with $\mathrm{W} 6 / 32$ and this level was reduced to $6-2 \%$ after $72 \mathrm{~h}$ in culture. Anti-CD68 for monocyte and macrophage labelled $4-5 \%$ of the cells after seeding and less than $3 \%$ after $72 \mathrm{~h}$. About $1 \%$ of the cells were stained with the endothelial cell marker Ulex europeaeus lectin.

The range of $\beta$-human chorionic gonadotropin released into the media was not significantly different between trophoblast cultured in the presence of 5.5 and $25 \mathrm{mmol} / \mathrm{l}$ glucose or $19.5 \mathrm{mmol} / \mathrm{l} \mathrm{D}-\mathrm{mannitol}$ plus $5.5 \mathrm{mmol} / \mathrm{l} \mathrm{D}$-glucose $(p=0.31$ and $p=0.24$, respectively; Table 1).

Electron microscopic examination showed a pale cytoplasm of the cells and pleomorphic nuclei with diffuse chromatin pattern. Common cytologic features included sparse stacks of rough endoplasmic reticulum, perinuclear Golgi apparatus, few mitochondria and a microvillous membrane on the media-facing surface (Fig.1). Trophoblasts were rich in coated pits and multiple coated vesicles containing electron dense material. Scattered endocytotic vesicles (multivesicular bodies) and lipid droplets were occasionally seen. Cells usually possessed bundles of 


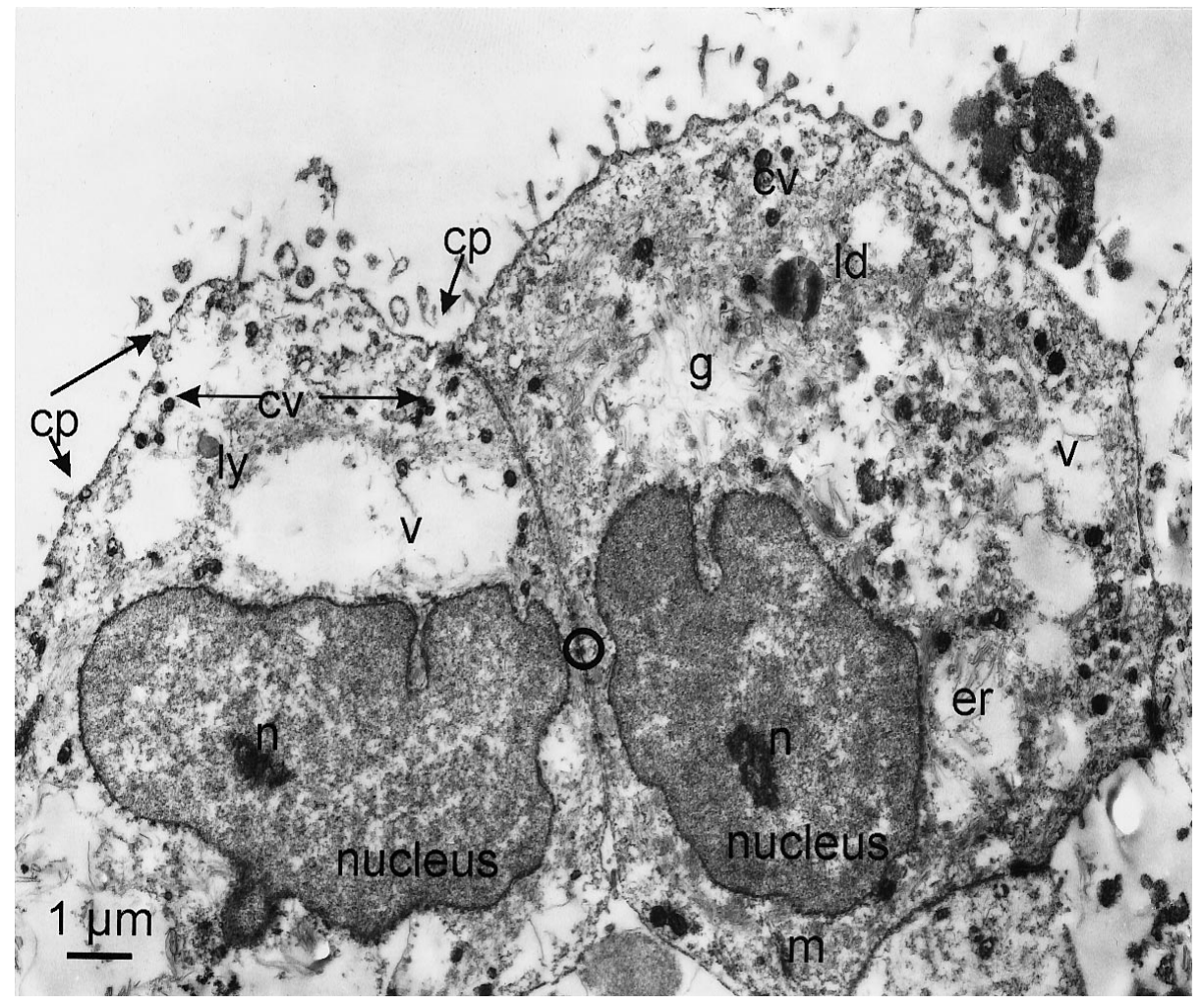

Fig. 1. Routine transmission electron microscopy of cultured human term placental trophoblast. Evident are pleomorphic nuclei with distinct nucleolus (n), segments of endoplasmic reticulum (er), Golgi apparatus (g), lysosomes (ly), mitochondrium (m), lipid droplets (ld), coated pits ( $\mathrm{cp}$ ), coated vesicles (cv), prominent cytoplasmic vacuoles (v) and intercellular desmosomal connections (encircled). Magnification: $\times 6500$

cytoplasmic intermediate filaments which are typical of epithelium including trophoblasts. Some had prominent cytoplasmic vacuoles. Small glycogen granula and larger aggregates were randomly distributed throughout the cytoplasm. Desmosomal connections between adjacent cells were frequently observed (Fig.1). Trophoblasts did not fuse to multinucleated syncytia even after $72 \mathrm{~h}$ regardless of the culture media.

GLUT1 distribution. Cultured trophoblast cells stained abundantly for GLUT1. Pre-embedding immunogold labelling revealed that $73 \%$ of total GLUT1 molecules reside in the trophoblast plasma membrane under basal conditions (Fig. 2). The majority of these cell surface transporters were located in the apical microvillous membrane, only $31 \%$ were visible in the basolateral membranes. Coated pits were generally devoid of label. Gold grains in the cells interior were found in clusters or singularily dispersed through the cytoplasm, being not preferably associated with glygogen aggregates.
Concomitantly with a reduced total GLUT1 expression $(-20 \% ; p<0.05)$ after culture of the cells in media containing $25 \mathrm{mmol} / 1$ glucose for $48 \mathrm{~h}$, the transporters were significantly redistributed resulting in a loss of $40 \%(p<0.05)$ in plasma membrane transporter labelling (Fig.3). The disappearance of cell surface transporters was more pronounced in the microvillous membrane $(-45 \% ; p<0.05)$ than in the basolateral membranes $(-23 \%)$, where this effect did not reach the level of statistical significance $(p=0.06$; Table 2$)$. Preliminary experiments showed similar effects on GLUT1 distribution also after 24 and $96 \mathrm{~h}$ hyperglycaemic culture. The hyperglycaemia-induced alterations were specific for D-glucose, as they were not reproduced by osmotic control media containing equimolar D-mannitol.

In control experiments with pre-immune serum or in which the primary antibody was omitted, total gold labelling per cell profile was reduced to $10 \%$ or less (not shown) of the particle count under control conditions.

Western blotting identified GLUT1 proteins with apparent molecular weights between 55-65 kDa (not shown), further confirming the specificity of the antiserum used in this study.

\section{Discussion}

Hyperglycaemia (i.e. diabetes) during pregnancy has principally deleterious metabolic effects on both mother and fetus $[24,25]$. The concept of fuel-medi- 


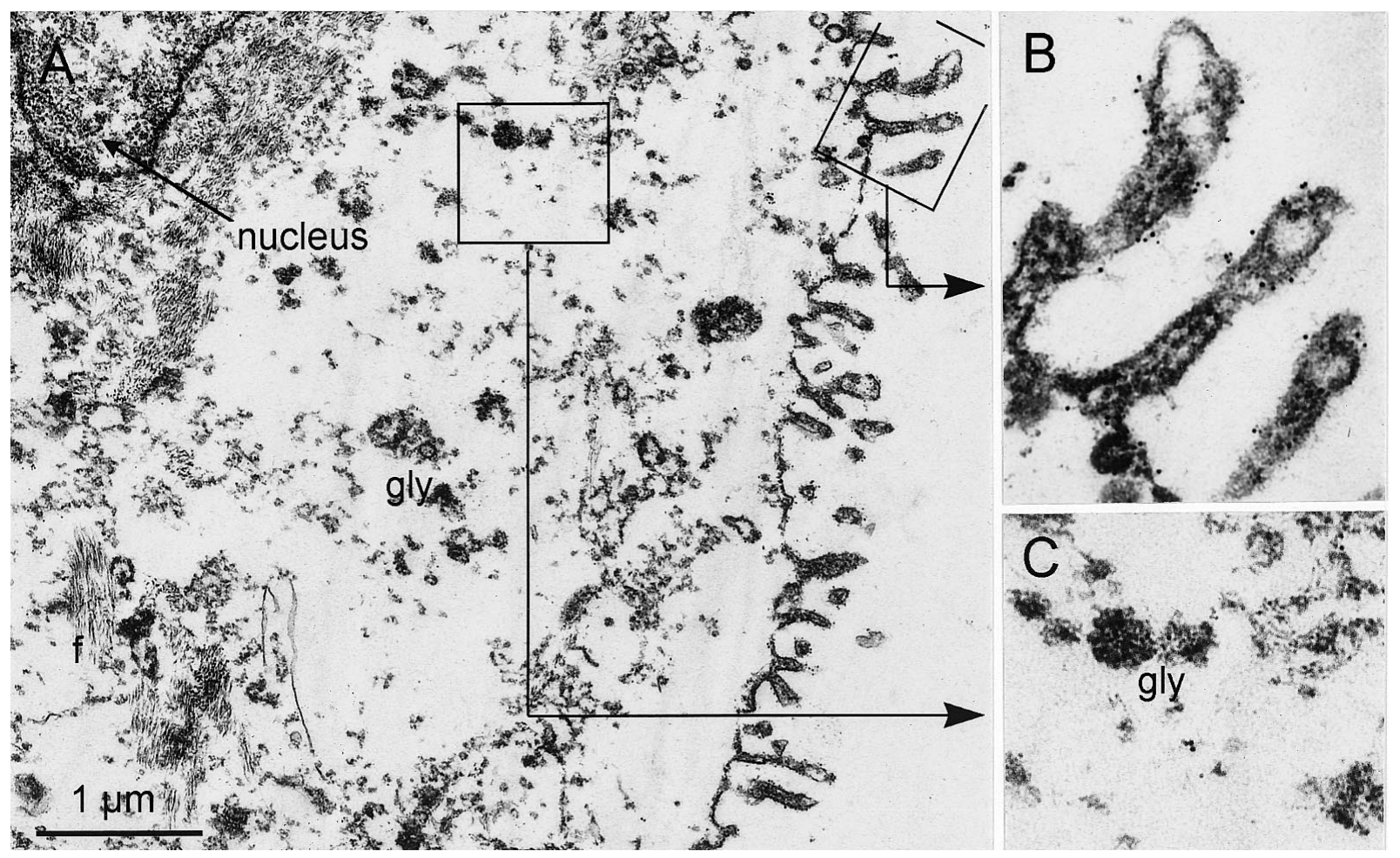

Fig. 2 A-C. Portion of trophoblast cultured in the presence of $5.5 \mathrm{mmol} / \mathrm{l}$ glucose (normoglycaemia) for $48 \mathrm{~h}$. Immunogold stained for GLUT1 (A, magnification: $\times 23000)$. Labelling was particularly prominent on the microvillous surface but within this membrane there was no preferential localization in the villi themselves $(\mathbf{B}$, magnification: $\times 75000)$. Only sparse cytoplasmic GLUT1 expression ( $\mathbf{C}$, magnification: $\times 50000)$. Actin-like filaments (f), clusters of glycogen (gly)

ated teratogenesis [26] implicates the placenta as the key organ in transducing maternal metabolic changes to the fetus [27]. Alterations in transplacental glucose transport could lead to fetal hyperglycaemia which can cause serious and occasionally life-threatening anomalies in the growing fetus. Adaptative longterm down-regulatory effects of glucose on its own uptake system have recently been shown in the human term placental trophoblast after 24,48 and $96 \mathrm{~h}$ culture under diabetes-like conditions [11, 12], as well as in midgestation rat trophoblast cells cultured

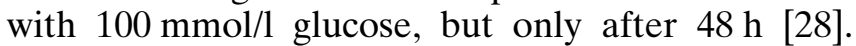
The reported changes in GLUT1 expression are apparently, however, not the only means by which transport activity is regulated.

The discrepancy between a $50 \%$ lower $\mathrm{V}_{\max }$ and a $20 \%$ reduction in total cellular GLUT1 protein with no change in $K_{M}$ [11] lead us to hypothesise the existence of mechanisms in addition to the reduction in steady-state GLUT1 protein concentrations. The results presented in this study strongly suggest that the post-translational regulation of trophoblast glucose transport activity by ambient glucose concentrations involves long-term changes in subcellular trafficking of the GLUT1 protein, thus generally providing morphological evidence for a redistribution of GLUT1 from the plasma membrane to intracellular sites in an insulin-insensitive tissue. Effects of hyperglycaemia for less than $24 \mathrm{~h}$ have not been investigated, therefore, the existence of short-term mechanisms cannot be ruled out.

As the nature of the intracellular storage compartments of GLUT1 in trophoblast cells is not clear, there are also no established markers allowing for the reliable identification of respective membranes with which GLUT1 might be associated. Therefore, quantitative studies into internalisation require other methods than subcellular fractionation. We studied this process at the electron-microscopical level in situ by immunogold labelling. Purity, viability and endocrine activity of the trophoblast cell preparations used were extensively characterised and validated. The results showed that the cells in culture were viable and highly purified trophoblast showing an intact plasma membrane and an internal architecture characteristic for trophoblast cells in situ [29]. According to current opinion, the increase in $\beta$-human chorionic gonadotropin (hCG) concentration during culture reflects a biochemical differentiation [30]. This was unaffected by hyperglycaemia, because hCG concentrations were unchanged. The presence of prominent endoplasmic reticulum and of well-developed Golgi apparatus indicates that the differentiated trophoblast in vitro possessed a high capacity for protein synthesis and secretion. 

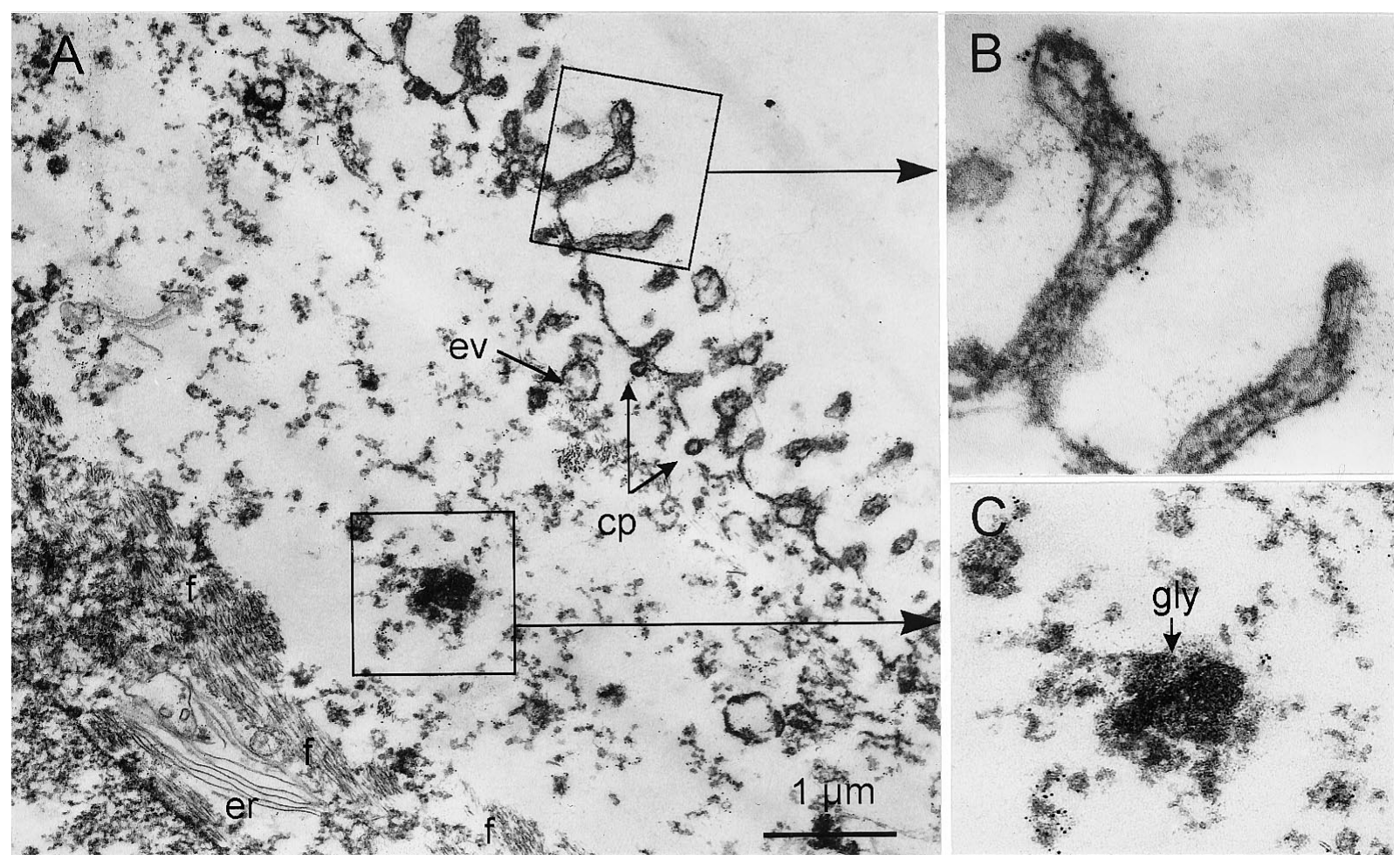

Fig. 3 A-C. Portion of trophoblast cultured in the presence of $25 \mathrm{mmol} / \mathrm{l}$ glucose (hyperglycaemia) for $48 \mathrm{~h}$. Immunogold stained for GLUT1 (A, magnification: $\times 18000)$. The microvillous plasma membrane is less intensively labelled than under normoglycaemic conditions (B, magnification: $\times 50000)$. Numerous gold grains appear in the cells interior in response to hyperglycaemia (C, magnification: $\times 40000)$. Flattened cisternae of endoplasmic reticulum (er), actin-like filaments (f), coated pits (cp), endocytotic vesicles (ev), cluster of glycogen (gly)

The GLUT1 glucose transporter protein is the major isoform expressed in the human placenta. It represents an asymmetric carrier and spans the lipid bilayer 12 times, with the carboxyl terminus exposed to the cytoplasmic face [4]. Our immunocytochemical data suggest that the penetration of antibodies beyond the surface membrane into the cell interior was not limited. Moreover, the efficiency of GLUT1 labelling in the plasma membrane and the intracellular organelles were obviously not different because, even though the total number of gold particles per cell profile decreased in response to hyperglycaemia, the intensity of intracellular labelling increased for cells treated with a high glucose concentration. Using SDS-PAGE followed by immunoblotting, trophoblast GLUT1 proteins migrated with apparent molecular weights between $55-65 \mathrm{kDa}$ as a characteristically broad band which is due to their heterogeneous glycosylation and consistent with data reported earlier [19,31-33].

It is well established, that the short-term hypoglycaemic effect of insulin in adipocytes, skeletal and cardiac muscle cells is achieved by the translocation of the insulin-regulatable transporter isoform GLUT4 from a cytoplasmic membrane fraction to the cell surface [34-39]. In contrast, GLUT1 trafficking upon short-term stimulation by insulin is controversial even in classical insulin-responsive tissues such as skeletal muscle [40]. In studies reporting on such effects, intracellular GLUT1, similar to GLUT4, translocates to the plasma membrane after short-term insulin stimulation in rat cardiac myocytes [39], in rat [41] as well as 3T3-L1 adipocytes [42] and after long-term insulin treatment in L6 skeletal muscle cells [43].

The results presented here indicate profound differences to the above conditions. The first is that, in contrast to non-stimulated GLUT4 that resides mainly in intracellular compartments [44, 45], GLUT1 was predominantly targeted to the trophoblast plasma membrane in control cells. The precise molecular basis of such isoform-specific intracellular sorting remains to be clarified but, apart from one study [46], there is now considerable agreement about a recruitment of GLUT1 to the cell surface under basal conditions in a number of cell types expressing it [20, 47-49]. Differential targeting information could reside in particular in the amino acid sequence of the four unique hydrophilic domains which display the highest degree of sequence heterogeneity among the GLUT family [21]. Moreover, specific post-translational modification of the molecules or interaction of the transporters with cytoskeletal elements could account for the distinct subcellular localisation of various glucose carriers [50]. 
Table 2. Subcellular distribution of GLUT1 labelling in human term placental trophoblast

\begin{tabular}{lll} 
Number of gold particles & \\
\hline $\begin{array}{l}\text { Normo- } \\
\text { glycaemia }\end{array}$ & $\begin{array}{l}\text { Hyper- } \\
\text { glycaemia }\end{array}$ & Osmotic control
\end{tabular}

\begin{tabular}{llll}
\hline $\begin{array}{l}\text { Microvillous } \\
\text { membrane }\end{array}$ & $644(413-951)$ & $355(217-693)^{\mathrm{a}}$ & $681(440-741)$ \\
$\begin{array}{l}\text { Basolateral } \\
\text { membrane }\end{array}$ & $197(107-235)$ & $152(96-227)$ & $206(138-220)$ \\
$\begin{array}{l}\text { Total plasma } \\
\text { membrane }\end{array}$ & $841(539-1154)$ & $507(336-894)^{\mathrm{a}}$ & $887(588-945)$ \\
$\begin{array}{l}\text { Cell interior } \\
\text { Total gold }\end{array}$ & $311(238-612)$ & $418(207-784)^{\mathrm{a}}$ & $293(235-586)$ \\
particles & $1152(799-1705)$ & $925(574-1586)^{\mathrm{a}}$ & $1180(827-1498)$ \\
\hline
\end{tabular}

Cells were cultured in the presence of either $5.5 \mathrm{mmol} / \mathrm{l} \mathrm{glu}-$ cose (normoglycaemia) or $25 \mathrm{mmol} / 1$ glucose (hyperglycae$\mathrm{mia}$ ) or $19.5 \mathrm{mmol} / \mathrm{l} \mathrm{D}$-mannitol plus $5.5 \mathrm{mmol} / \mathrm{l} \mathrm{D}$-glucose (osmotic control), respectively, for $48 \mathrm{~h}$. Data are medians and (range). ${ }^{\mathrm{a}} p<0.05$ vs normoglycaemia

The second difference is in the direction of hyperglycaemia-induced GLUT1 subcellular redistribution in placental trophoblast that is opposite to the insulin-induced GLUT1 and GLUT4 trafficking towards the plasma membrane described in other cells. Our data are consistent with translocation of the transporters from the cell surface to the intracellular compartment in response to hyperglycaemia.

Due to the limitations of the immunogold method, we cannot, however, entirely exclude the possibility that hyperglycaemia selectively caused a lower turnover rate of cytoplasmic transporters, nor can we provide conclusive information on the molecular machinery bringing about the GLUT1 internalisation. Cytoplasmic GLUT1 labelling showed no apparent association with definable intracellular membranes. Considering the entry mechanism of the ligand glucose into the cell [4], it comes as no surprise that no transporters were found within structures commonly related to receptor-mediated endocytosis, i.e. coated pits and coated vesicles. Indeed, GLUT1 itself, found in the cytoplasm, could have been taken up by nonspecific fluid-phase endocytosis, which does not involve coated pits and coated vesicles. The general failure to find the transporters in vesicles of the endocytotic pathway could either reflect the low probability of rendering a specific protein visible during the endocytotic process in the very small areas that can be seen in the electron microscope. Alternatively it could be merely caused by the poor preservation of structure which is due to the obligatory compromise between maintenance of antigenicity and morphological integrity when using the immunogold procedure.

In conclusion, we postulate that in addition to down-regulating human term placental trophoblast GLUT1 expression, glucose exerts its autoregulatory effect on hexose transport by promoting GLUT1 subcellular trafficking in favour of carrier partitioning to intracellular sites.

Acknowledgements. Our sincere thanks go to R. Schmied and I. Greiner for excellent technical assistance and to the Austrian Science Foundation (FWF; grant P13721-MED) as well as the Jubilee Fund of the Austrian National Bank (grant 7361) for financial support.

\section{References}

1. Kalhan SC, D’Angelo LJ, Savin SM, Adam PAJ (1979) Glucose production in pregnant women at term gestation. J Clin Invest 63: 388-394

2. Sibley CP, Boyd RDH (1992) Mechanisms of transfer across the human placenta. In: Polin RA, Fox WW (eds) Fetal and neonatal physiology, vol 1. Saunders, Philadelphia, pp 62-74

3. Stein WD (1967) The movement of molecules across cell membranes. Academic Press, New York

4. Mueckler M (1994) Facilitative glucose transporters. Eur J Biochem 219: 713-725

5. Waddell ID, Scott HM, Grant A, Burchell A (1991) Identification and characterization of a hepatic microsomal glucose transport protein. Biochem J 275: 363-367

6. Hahn T, Hartmann M, Blaschitz A et al. (1995) Localization of the high affinity facilitative glucose transporter protein GLUT1 in the human, marmoset-monkey (Callithrix jacchus) and rat placentae at different developmental stages. Cell Tissue Res 280: 49-57

7. Schneider H (1996) Ontogenic changes in the nutritive function of the placenta. Placenta 17: 15-26

8. Hahn T, Barth S, Graf R et al. (1999) Placental glucose transporter expression is regulated by glucocorticoids. J Clin Endocrinol Metab 84: 1445-1452

9. Testar X, Lasuncion MA, Chieri R, Herrera E (1985) Effects of exogenous insulin on placental transfer of maternal glucose to the rat fetus. Diabetologia 28: 743-748

10. Challier JC, Hauguel S, Desmaizieres V (1986) Effect of insulin on glucose uptake and metabolism in the human placenta. J Clin Endocrinol Metab 62: 803-807

11. Hahn T, Barth S, Weiss U, Mosgoeller W, Desoye G (1998) Sustained hyperglycaemia in vitro downregulates the GLUT1 glucose transport system of cultured human term placental trophoblast. A mechanism to protect fetal development? FASEB J 12: 1221-1231

12. Illsley NP, Sellers MC, Wright RL (1998) Glycaemic regulation of glucose transporter expression and activity in the human placenta. Placenta 19: 517-524

13. Hahn T, Barth S, Hofmann W, Reich O, Lang I, Desoye G (1998) Hyperglycaemia regulates the glucose transport system of clonal choriocarcinoma cells in vitro. A potential molecular mechanism contributing to the adjunct effect of glucose in tumor therapy. Int J Cancer 78: 353-360

14. Schmon B, Hartmann M, Jones CJ, Desoye G (1991) Insulin and glucose do not affect the glycogen content in isolated and cultured cells of human term placentae. J Clin Endocrinol Metab 73: 888-893

15. Shorter SC, Starkey PM, Ferry BL, Clover LM, Sargent IL, Redman CWG (1993) Antigenic heterogeneity of human cytotrophoblast and evidence for the transient expression of MHC class I antigens distinct from HLA-G. Placenta 14: $571-582$ 
16. Beham A, Denk H, Desoye G (1988) The distribution of intermediate filament proteins, actin and desmoplakins in human placental tissue as revealed by polyclonal and monoclonal antibodies. Placenta 9: 479-492

17. Lang I, Hartmann M, Blaschitz A, Dohr G, Skofitsch G, Desoye G (1993) Immunohistochemical evidence for the heterogeneity of maternal and fetal vascular endothelial cells in human full-term placenta. Cell Tissue Res 274: 211-218

18. Birnbaum MJ, Haspel HC, Rosen OM (1986) Cloning and characterization of a cDNA encoding the rat brain glucose-transporter protein. Proc Natl Acad Sci USA 83: 5784-5788

19. Haspel HC, Rosenfeld MG, Rosen OM (1988) Characterization of antisera to a synthetic carboxyl-terminal peptide of the glucose transporter protein. J Biol Chem 263: 398-403

20. Haney PM, Slot JW, Piper RC, James DE, Mueckler M (1991) Intracellular targeting of the insulin-regulatable glucose transporter (GLUT4) is isoform specific and independent of cell type. J Cell Biol 114: 689-699

21. Harris DS, Slot JW, Geuze HJ, James DE (1992) Polarized distribution of glucose transporter isoforms in Caco- 2 cells. Proc Natl Acad Sci USA 89: 7556-7560

22. Blok J, Gibbs EM, Lienhard GE, Slot JW, Geuze HJ (1988) Insulin-induced translocation of glucose transporters from post-Golgi compartments to the plasma membrane of 3T3-L1 adipocytes. J Cell Biol 106: 69-76

23. Lowry OH, Rosebrough NJ, Farr AL, Randall RJ (1951) Protein measurement with the Folin phenol reagent. J Biol Chem 193: 265-275

24. Buchanan TA, Kjos SL (1994) Diabetes and pregnancy. Curr Ther Endocrinol Metab 5: 278-283

25. Eriksson UJ (1996) Lifelong consequences of metabolic adaptations in utero? Diabetologia 39: 1123-1125

26. Freinkel N (1980) The Banting Lecture 1980: of pregnancy and progeny. Diabetes 29: 1023-1035

27. Desoye G, Shafrir E (1994) Placental metabolism and its regulation in health and diabetes. Mol Aspects Med 15: 505-682

28. Das UG, Sadiq HF, Soares MJ, Hay WW Jr, Devaskar SU (1998) Time-dependent physiological regulation of rodent and ovine placental glucose transporter (GLUT-1) protein. Am J Physiol 274:R339-R347

29. Benirschke K, Kaufmann P (1995) Pathology of the human placenta. 3rd edn. Springer, Berlin Heidelberg New York

30. Cervar M, Blaschitz A, Dohr G, Desoye G (1999) Paracrine regulation of distinct trophoblast functions in vitro by placental macrophages. Cell Tissue Res 295: 297-305

31. Haspel HC, Birnbaum MJ, Wilk EW, Rosen EM (1985) Biosynthetic precursors and in vitro translation products of the glucose transporter of human hepatocarcinoma cells, human fibroblasts, and murine preadipocytes. J Biol Chem 260: 7219-7225

32. Boileau P, Mrejen C, Girard J, Hauguel-de Mouzon S (1995) Overexpression of GLUT3 placental glucose transporter in diabetic rats. J Clin Invest 96: 309-317

33. Barros LF, Yudilevich DL, Jarvis SM, Beaumont N, Baldwin SA (1995) Quantitation and immunolocalization of glucose transporters in the human placenta. Placenta 16: 623-633

34. Malide D, Cushman SW (1997) Morphological effects of wortmannin on the endosomal system and GLUT4-con- taining compartments in rat adipose cells. J Cell Sci 110: 2795-2806

35. Slot JW, Geuze HJ, Gigengack S, Lienhard GE, James DE (1991) Immuno-localization of the insulin regulatable glucose transporter in brown adipose tissue of the rat. J Cell Biol 113: 123-135

36. Guillet-Deniau I, Leturque A, Girard J (1994) Expression and cellular localization of glucose transporters (GLUT1, GLUT3, GLUT4) during differentiation of myogenic cells isolated from rat foetuses. J Cell Sci 107: 487-496

37. Kozka IJ, Clark AE, Reckless JP, Cushman SW, Gould GW, Holman GD (1995) The effects of insulin on the level and activity of the GLUT4 present in human adipose cells. Diabetologia 38: 661-666

38. Zierath JR, He L, Guma A, Odegoard-Wahlstrom E, Klip A, Wallberg-Henriksson H (1996) Insulin action on glucose transport and plasma membrane GLUT4 content in skeletal muscle from patients with NIDDM. Diabetologia 39: 1180-1189

39. Zorzano A, Sevilla L, Camps M et al. (1997) Regulation of glucose transport, and glucose transporters expression and trafficking in the heart: studies in cardiac myocytes. Am J Cardiol 80: 65A-76A

40. Galante P, Maerker E, Scholz R et al. (1994) Insulin-induced translocation of GLUT 4 in skeletal muscle of insulin-resistant Zucker rats. Diabetologia 37: 3-9

41. Zorzano A, Wilkinson W, Kotliar N et al. (1989) Insulinregulated glucose uptake in rat adipocytes is mediated by two transporter isoforms present in at least two vesicle populations. J Biol Chem 264: 12358-12363

42. Clancy BM, Czech MP (1990) Hexose transport stimulation and membrane redistribution of glucose transporter isoforms in response to cholera toxin, dibutyryl cyclic AMP, and insulin in 3T3-L1 adipocytes. J Biol Chem 265: 12434-12443

43. Klip A, Ramlal T, Bilan PJ, Marette A, Liu Z, Mitsumoto $\mathrm{Y}$ (1993) What signals are involved in the stimulation of glucose transport by insulin in muscle cells? Cell Signal 5: 519-529

44. Holman GD, Cushman SW (1994) Subcellular localization and trafficking of the GLUT4 glucose transporter isoform in insulin-responsive cells. Bioessays 16: 753-759

45. Rea S, James DE (1997) Moving GLUT4: the biogenesis and trafficking of GLUT4 storage vesicles. Diabetes 46: $1667-1677$

46. Greco-Perotto R, Wertheimer E, Jeanrenaud B, Cerasi E, Sasson S (1992) Glucose regulates its transport in L8 myocytes by modulating cellular trafficking of the transporter GLUT-1. Biochem J 286: 157-163

47. Piper RC, Hess LJ, James DE (1991) Differential sorting of two glucose transporters expressed in insulin-sensitive cells. Am J Physiol 260: C570-C580

48. Asano T, Takata K, Katagiri H et al. (1992) Domains responsible for the differential targeting of glucose transporter isoforms. J Biol Chem 267: 19636-19641

49. Shibasaki Y, Asano T, Lin JL et al. (1992) Two glucose transporter isoforms are sorted differentially and are expressed in distinct cellular compartments. Biochem J 281: 829-834

50. Takata K, Kasahara M, Oka Y, Hirano H (1993) Mammalian sugar transporters: Their localization and link to cellular functions. Acta Histochem Cytochem 26: 165-178 